\title{
EVALUASI KESESUAIAN LAHAN DAN KELAYAKAN EKONOMI TANAMAN KAKAO DI KECAMATAN GANTARANG KEKE KABUPATEN BANTAENG
}

\section{(Land Suitability Evaluation and Economic Feasibility of Cocoa Crop in the Sub District of Gantarangkeke, Bantaeng District)}

\author{
Wahyuni Mustaman ${ }^{1)}$, Amir Tjoneng ${ }^{2)}$, Abdullah ${ }^{2)}$ \\ ${ }^{1)}$ Program Studi Agroteknologi, Program Pascasarjana Universitas Muslim Indonesia \\ ${ }^{2)}$ Program Studi Agroteknologi, Fakultas Pertanian Universitas Muslim Indonesia \\ Email:wahyunimustaman@gmail.com
}

\begin{abstract}
The potential of a land for certain uses can be predicted through land evaluation activities. This study aims to 1) evaluate the suitability of the land, 2) analyze the limiting factors and land improvement measures, and 3) analyze the economic feasibility of cocoa plant development carried out in Gantarangkeke, Bantaeng district during April to October 2018. This study uses a parametric approach with qualitative and quantitative mixed methods, field surveys using purposive sampling, biophysical land suitability analysis using a parametric approach (Sys et al., 1991) while economic analysis analyzes the economic feasibility equivalent of rice consumption according to Sajogyo (1977) with rice consumption needs in the village is $320 \mathrm{~kg} /$ year and the income-cost ratio $(R / C)$. The result of the study shows that the climate type of the study area according to Schmidt-Ferguson is classified as $B$ (wet) with the actual cocoa land suitability class classified as marginal (S3) and not suitable at this time (N1) with climate limiting factors (relative air humidity) where corrective actions cannot taken, soil physical characteristic (soil depth and coarse fragments) which cannot be corrected, and soil fertility (c-organic) with the addition of organic materials. The average income of farmers that classified class S3 is Rp. 13.901.650/th and N1 is Rp. 7.656.600/th, therefore the research area has a decent life if it the family that classified class S3 with size consists of 4 person with total expenditure of Rp. 12.800 .000 and N1 with size consists of 2 person with total expenditure of $R p$. 6.400.000. In 2017, income per capita of Bantaeng district is Rp. 856.592 that classified class S3 with size consists of 4 person is Rp. 3.426 .368 and N1 with size consists of 2 person is $R p$. 1.713.184 with the value of the $R$-C ratio ranging from 3.40 to 4.90 , which means that it is feasible to develop cocoa plants in Gantarangkeke Subdistrict since the $R / C$ value still greater than 1 .
\end{abstract}

Keywords:Land suitability, Evaluation, Cocoa, Gantarangkeke

\section{PENDAHULUAN}

Sub sektor perkebunan merupakan salah satu sub sektor yang cukup besar potensinya. Kontribusi sub sektor perkebunan dalam PDB yaitu sekitar 3.57 \% pada tahun 2016 atau merupakan urutan pertama di sektor pertanian, peternakan, perburuan dan jasa pertanian. Sub sektor ini merupakan penyedia bahan baku untuk sektor industri, penyerap tenaga kerja, dan penghasil devisa (BPS, 2016).

\section{Kakao (Theobroma cacao L.)} merupakan salah satu komoditi hasil perkebunan yang mempunyai peran cukup penting dalam kegiatan perekonomian dan komoditas ekspor sebagai penghasil devisa negara selain minyak dan gas di Indonesia. Indonesia merupakan negara 
produsen dan eksportir kakao terbesar kakao selama 5 tahun terakhir (2013 ketiga dunia setelah Ghana dan Pantai 2017) yaitu rata-rata 0.56 ton/ha (BPS Gading. Pada tahun 2012 total volume ekspor mencapai 387.79 ribu ton dengan Kabupaten Bantaeng, 2018). Hal ini mengindikasikan kenaikan produktivitas total nilai sebesar US\$ 1.12 milyar, meskipun sedikit jika dibandingkan menurun menjadi 330.03 ribu ton pada tahun 2016 dengan total nilai sebesar US\$ 1.24 milyar (BPS, 2016).

Sulawesi Selatan merupakan sentra produksi kakao terbesar ke dua di Indonesia dengan kontribusi sebesar 16.59\% (Pusdatin Pertanian, 2016) dan termasuk pengekspor beberapa komoditi pertanian. Kakao termasuk komoditas ekspor pertanian yang memiliki nilai ekspor tertinggi dalam kurun waktu 2014 - 2016 dengan nilai mencapai 159.56 Juta US\$ dengan produktivitas rata-rata Sulawesi Selatan tahun 2011 - 2016 sebanyak 0.46 ton/ha (BPS Provinsi Sulawesi Selatan, 2017).

\section{Kecamatan}

Gantarangkeke merupakan salah satu kecamatan di Kabupaten Bantaeng yang didominasi oleh sektor pertanian. Hampir seluruh penduduknya bergerak di bidang pertanian, utamanya tanaman pangan dan perkebunan. Daerah ini adalah salah satu penghasil kakao terbesar dibandingkan dengan kecamatan lain dan unggulan di Kabupaten Bantaeng dengan produktivitas dengan produktivitas rata-rata Sulawesi Selatan 0.46 ton/ha (BPS Provinsi Sulawesi Selatan, 2017). Selain itu, jika dikaitkan dengan produktivitas optimal yang dapat dicapai tanaman kakao menurut Sys et al. (1993) pada kisaran 1.5 ton/ha, maka produktivitas kakao di Kecamatan Gantarangkeke masih tergolong rendah.

Kendala utama dalam pengembangan kakao di Indonesia adalah produktivitas kakao masih rendah akibat serangan hama penggerek buah kakao (PBK) dan pemilihan lahan untuk tanaman kakao yang tidak mempertimbangkan kondisi tanah dan iklim yang sesuai untuk pertumbuhan tanaman kakao (Goenadi et al., 2005) sehingga kemampuan tanah untuk menunjang produksi kakao secara optimal tidak tercapai. Oleh karena itu, untuk meningkatkan produksi kakao dapat dilakukan kegiatan intensifikasi dan ektensifikasi lahan. Dalam rangka pembukaan lahan baru yang paling sesuai, sebaiknya didasarkan pada hasil evaluasi 
lahan sehingga memenuhi persyaratan tumbuh tanaman kakao dan sesuai dengan potensi produksinya (Balittri, 2012 dalam Yatno, 2016).

Untuk mengetahui potensi suatu lahan untuk penggunaan tertentu dapat dilakukan evaluasi lahan. Evaluasi lahan merupakan suatu proses memperkirakan potensi lahan untuk beberapa jenis penggunaan lahan alternatif (Dent dan Young, 1981 dalam Baja, 2012a). Evaluasi lahan pada dasarnya membicarakan dua aspek utama dari lahan yaitu: sumber daya fisik seperti tanah, topografi, dan iklim serta sumber daya sosial ekonomi seperti kepemilikan lahan, tingkat pengelolaan, ketersediaan tenaga kerja, pasar, dan aktivitas lain dari manusia (Lopulisa dan Husni, 2011).

Penilaian potensi lahan didasari pada hasil evaluasi kesesuaian lahan pada unit evaluasi yang dapat dinilai dengan pendekatan parametrik, penilaian evaluasi dapat dilakukan dengan bersifat kualitatif dan kuantitatif. Menurut Baja (2012a), pendekatan kualitatif penilaian sumber daya lahan berfokus terutama pada faktorfaktor biofisik. Menurut Baja (2012b), evaluasi lahan secara kualitatif menggunakan faktor biofisik internal diperoleh melalui penyelidikan tanah pada profil tertentu mencakup kualitas lahan sebagai indikator kesesuaian lahan dan biofisik eksternal berupa kualitas ekologi, berkaitan dengan prasyaratan ekologi (iklim, tanah, hidrologi, biologi, dan lainlain). Berbeda dengan pendekatan kualitatif, evaluasi kuantitatif memberi penekanan pada aspek ekonomi (Baja, 2012a).

Menurut Lopulisa dan Husni (2001) bahwa pendekatan parametrik merupakan evaluasi karakteristik lahan dengan menggunakan harkat atau bobot yang berbeda dari setiap tingkatan pembatas karakteristik lahan dalam suatu skala angka dari maksimum (umumnya 100) sampai suatu nilai minimum. Pendekatan parametrik menekankan kuantifikasi, penilaian, pembobotan, dan penerapan operasi matematika (Sys, 1985 dalam Baja, 2012b), sementara dalam metode faktor pembatas, proses evaluasi dan klasifikasi hanya menggunakan nilai satuan baku kualitas dan karakteristik lahan. Pendekatan parametrik sebenarnya hanya merupakan perbaikan (refinement) metode evaluasi dengan menggunakan faktor pembatas (Baja, 2012b). Sistem parametrik dalam hal prosedur penilaian lahan yang khusus dibuat untuk 
menyempurnakan sistem faktor pembatas (Baja, 2012a).

Berdasarkan produktivitas kakao di Kecamatan Gantarangkeke yang lebih rendah jika dibandingkan dengan produktivitas optimalnya maka perlu dilakukan penelitian mengenai kesesuaian lahan dan kelayakannya dengan judul: Evaluasi Kesesuaian Lahan dan Kelayakan Ekonomi Tanaman Kakao di Kecamatan Gantarangkeke, Kabupaten

Bantaeng. Informasi kelas kesesuaian lahan untuk tanaman kakao dapat dimanfaatkan dalam usaha-usaha perbaikan pengembangan tanaman perkebunan ini agar potensi meningkatkan produktivitasnya melalui identifikasi kelas kesesuaian lahan.

Penelitian ini bertujuan 1)mengevaluasitingkatkesesuaianlahanbag i tanaman kakao di KecamatanGantarangkekeKabupatenBant aeng, 2)menganalisis faktor - faktor pembatas dan tindakan perbaikan lahan yang dapat dilakukan bagi tanaman kakao, dan

3)menganalisiskelayakanekonomipengem bangan tanaman kakao di Kecamatan Gantarangkeke Kabupaten Bantaeng. Sehingga penelitian ini diharapkan dapat menjadi bahan informasi dan pertimbangan bagi perencanaan penggunaan lahan untuk pengembangan kakao di Kecamatan Gantarangkeke sesuai dengan tingkat kesesuaian lahan.

\section{METODE PENELITIAN}

\section{Lokasi Penelitian}

Penelitian ini dilaksanakan di Kecamatan Gantarangkeke, Kabupaten Bantaeng (Gambar 1) yang dilaksanakan pada bulan April sampai Oktober 2018. Penelitian ini menggunakan pendekatan parametric mixed methods kualitatif dan kuantitatif. Metode kualitatif digunakan dalam analisis sedangkan metode kuantitatif dengan menggunakan indeks kesesuaian lahan diterapkan untuk analisis ekonomi untuk menilai usaha tani kakao di lokasi penelitian dengan menganalisis pendapatan petani setara dengan konsumsi beras menurut Sajogyo (1977), pendapatan per kapita Kabupaten Bantaeng, dan mengalisis R/C Ratio (Return Cost) melalui wawancara dengan petani. Analisis kesesuaian lahan menggunakan pendekatan parametrik (Sys et al., 1991). Metode penentuan titik lokasi profil dilakukan dengan purposive sampling yaitu melakukan pengambilan contoh tanah pada lokasi yang memiliki tanaman kakao dengan 6 titik pengamatan 
pada masing-masing desa selanjutnya contoh tanah dianalisis di laboratorium.

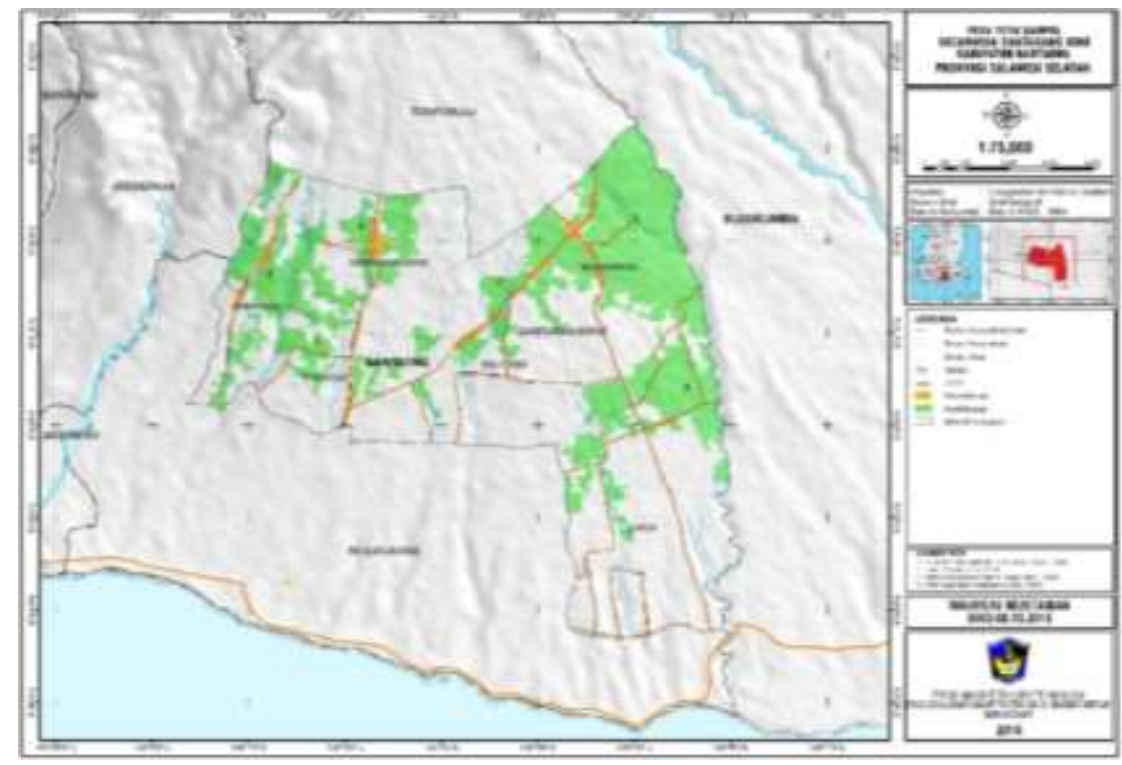

Gambar 1. Lokasi Penelitian

\section{Evaluasi Kesesuaian Lahan}

Penetapan indeks dan kelas kesesuaian iklim dan lahan dilakukan berdasarkan pendekatan parametrik (Sys et al., 1991) yang dianalisis sesuai persyaratan iklim dan tanah untuk tanaman kakao menurut Sys et al. (1993) (Appendix 1 dan 2).Selanjutnya penetapan indeks iklim dan lahan menggunakan metode square root ditunjukkan pada persamaan 1 dan 2.

$\mathrm{Ic}=R \min \sqrt{\frac{A}{100} \times \frac{B}{100} \times \frac{C}{100}}$

$R c=(0,9 \times I c)+16,67(\mathrm{Jika}, 25<I c<$ 92,5)

$R c=(1,6 \times I c)($ Jika,$I c<25)$

Keterangan:

Ic = indeks iklim
$\boldsymbol{R} \boldsymbol{c}=$ rating iklim

Rmin $\quad=$ karakteristik iklim paling rendah

$\boldsymbol{A}, \boldsymbol{B}, \boldsymbol{C} . . . .=$ rating karakteristik iklim lain selain minimum

$\mathrm{I}=\operatorname{Rmin} \sqrt{\frac{A}{100} \times \frac{B}{100} \times \frac{C}{100}}$

Keterangan:

I = indeks lahan

Rmin $=$ rating karakteristik lahan yang paling rendah

$\boldsymbol{A}, \boldsymbol{B}, \boldsymbol{C} . . . . .=$ rating karakteristik lahan lain selain minimum

Kelas kesesuaian lahan dibagi secara kualitatif yaitu indeks lahan $>75$ adalah kelas S1 (highly suitable), 50-75 adalah kelas S2 (moderately suitable), 2550 adalah kelas S3 (marginally suitable) dan $<25 \mathrm{~N}$ (non suitable) untuk kriteria 
kesesuaian lahan tanaman kakao menurut Sys et al. (1993).

\section{Analisis Ekonomi}

Analisa ekonomi yang dimaksud yaitu menghitung pendapatan usahatani sebagai selisih antara penerimaan dan semua biaya dan menghitung nilai $\mathrm{R} / \mathrm{C}$ atau singkatan dari return cost ratio, atau dikenal sebagai perbandingan (nisbah) antara penerimaan dan biaya. Secara matematik, hal ini dapat dituliskan pada persamaan 3 dan 4 (Soekartawi, 1995):

$$
\begin{gathered}
P d=R-C \quad \ldots \ldots \ldots \ldots(3) \\
a=\frac{R}{C} \quad \ldots \ldots \ldots \ldots \ldots(4) \\
\text { atau } \\
\mathrm{R}=\mathrm{Py} \times \mathrm{Y} \\
\mathrm{C}=\mathrm{FC}+\mathrm{VC} \\
\mathrm{Pd}=\left\{\begin{array}{c}
(\mathrm{Py} \times \mathrm{Y})-(\mathrm{FC}+\mathrm{VC})\} \\
\mathrm{a}=\frac{(\mathrm{Py} \times \mathrm{Y})}{(\mathrm{FC}+\mathrm{VC})}
\end{array}\right.
\end{gathered}
$$

Keterangan:

$\mathrm{Pd}=$ selisih antara total penerimaan dan total biaya

Py = harga output

$\mathrm{a}=$ nisbah antara total penerimaan dan total biaya

$\mathrm{Y}=$ output

$\mathrm{R}=$ total penerimaan

$\mathrm{FC}=$ biaya tetap $($ fix cost $)$

$\mathrm{C}=$ total biaya

$\mathrm{VC}=$ biaya variable $($ variable cost $)$

Jika $\mathrm{R} / \mathrm{C}$ ratio > 1 , berarti layak untuk diusahakan karena memberikan keuntungan. Jika $\mathrm{R} / \mathrm{C}$ ratio $=1$, berarti usaha tidak untung dan tidak rugi. Jika $\mathrm{R} / \mathrm{C}$ ratio $<1$, berarti tidak layak untuk diusahakan karena mengalami kerugian.

Penentuan kelayakan ekonomi dengan membandingkan antara pendapatan yang diperoleh petani dengan tingkat kesetaraan beras menurut Sajogyo (1977) dan pendapatan per kapita Kabupaten Bantaeng.

\section{HASIL DAN PEMBAHASAN}

\section{Karateristik Iklim Lokasi Penelitian}

Curah hujan lokasi penelitian satelit CHIRPS (2008-2017) berada pada kisaran $\pm 300-2500 \mathrm{~mm} / \mathrm{tahun}$, maka iklim Kecamatan Gantarangkeke menurut Schmidt-Ferguson termasuk tipe iklim B dengan jumlah bulan basah 8 dan bulan kering 2. Daerah penelitian memiliki temperatur rata-rata adalah $23^{\circ} \mathrm{C}$, temperatur minimum berkisar $21^{\circ} \mathrm{C}$ dan temperatur maksimum adalah $26^{\circ} \mathrm{C}$. Suhu optimum tanaman kakao15-30 ${ }^{\circ} \mathrm{C}$. Kelembaban udara relatif pada lokasi penelitian berkisar 92 - 94\%.Menurut Sys et al. (1993) bahwa kelembaban relatif optimum untuk tanaman kakao yaitu 35 $75 \%$. 


\section{Karakteristik Lahan Lokasi Penelitian}

Hasil overlay data citra, peta lereng dan RBI menghasilkan 6titik sampel. Lokasi penelitian keadaan fisiografinya yaitu tipe datar dengan kelerengan 0-3\% dengan ketinggian berkisar $143-222$ mdpl yang berada pada formasi batuan Qlvb dengan jenis tanah yaitu Inceptisol dan tekstur tanah yaitu lempung berdebu, Penggunaan lahan daerah penelitian berupa hutan, pemukiman, kebun, sawah irigasi, dan tegalan.

\section{Analisis Kesesuaian Lahan Kakao}

Analisis kesesuaian lahan pertamatama dengan menganalisis kesesuaian iklim di lokasi penelitian yang tergolong S3 (sesuai marginal) dengan faktor pembatas kelembaban relatif udara di tunjukkan pada Tabel 1.

Karakteristik iklim yang merupakan faktor pembatas tanaman adalah kelembaban relatif udara yang tidak dapat dilakukan perbaikan karena kondisi kelembaban sangat sulit dirubah meskipun dengan input teknologi (membutuhkan tenaga dan biaya yang tinggi). Kondisi kelembaban yang ada di lokasi penelitian yakni berkisar $90 \%$. Hal tersebut merupakan kelembaban yang tinggi untuk tanaman kakao dan kemungkinan kakao tidak dapat tumbuh dan berkembang dengan baik pada tingkat kelembaban yang tinggi atau diatas $80 \%$. Menurut Sys et al. (1993) bahwa pertumbuhan dan produksi kakao banyak ditentukan oleh ketersediaan air sehingga kakao dapat tumbuh dan berproduksi dengan baik di tempat yang jumlah curah hujannya relatif sedikit tetapi merata sepanjang tahun dan kelembaban udara relatif sebaiknya dibawah $80 \%$ karena kelembaban yang berlebihan dapat meningkatkan tingkat serangan hama dan penyakit.

Tabel 1. Kesesuaian iklim kakao di lokasi penelitian

\begin{tabular}{lcc}
\hline \multicolumn{1}{c}{ Parameter } & Data & Nilai \\
\hline \hline CH tahunan $(\mathrm{mm})$ & 2235 & 90 \\
Lamanya bulan kering & 2 & 85 \\
Rata-rata suhu tahunan $\left({ }^{\circ} \mathrm{C}\right)$ & 23 & 85 \\
$\begin{array}{l}\text { Rata-rata suhu tahunan max } \\
\left({ }^{\circ} \mathrm{C}\right)\end{array}$ & 26 & 100 \\
Rata-rata suhu tahunan min & 21 & 100 \\
$\left({ }^{\circ} \mathrm{C}\right)$ & \\
$\mathrm{RH}(\%)$ & 93 & 40 \\
\hline \hline \multicolumn{2}{c}{ Indeks Iklim (IC) (Square root) } & $\mathbf{3 2 . 2 2}$ \\
\multicolumn{2}{c}{ Kesesuaian Iklim } & $\mathbf{S 3}$ \\
\hline \hline
\end{tabular}

Selanjutnya dari hasil perhitungan indeks iklim (IC) kemudian dikonversi menjadi bobot iklim yaitu 46. Kemudian menghitung nilai indeks lahan dari hasil perhitungan karakteristik lahan yang 
melibatkan bobot iklim ditunjukkan pada (N1) dengan faktor pembatas adalah Tabel 2, maka kelas kesesuaian lahan kedalaman tanah, fragmen kasar, dan Cpada daerah penelitian adalah sesuai organik dengan nilai indeks lahan berkisar marginal (S3) dan tidak sesuai saat ini antara 16-25.

Tabel 2.Indeks kesesuaian lahan dan faktor pembatas kakao di lokasi penelitian

\begin{tabular}{ccccc}
\hline \hline Titik & Indeks & Kelas & Faktor Pembatas & Luas (Ha) \\
\hline \hline 1 & 25 & S3 & Kedalaman tanah dan fragmen kasar & 140 \\
2 & 24 & N1 & Kedalaman tanah & 257 \\
3 & 22 & N1 & Kedalaman tanah dan carbon organik & 565 \\
4 & 16 & N1 & Kedalaman tanah, fragmen kasar dan & 414 \\
5 & 18 & N1 & Kedalaman tanah dan fragmen kasar & 359 \\
6 & 25 & S3 & Kedalaman tanah dan fragmen kasar & 149 \\
\hline \hline
\end{tabular}

Tabel 3.Kelas kesesuaian lahan dan faktor pembatas kakao di lokasi penelitian

\begin{tabular}{|c|c|c|c|c|}
\hline Titik & Aktual & Faktor pembatas & $\begin{array}{c}\text { Tingkat } \\
\text { pengelolaan }\end{array}$ & Perbaikan \\
\hline 1 & $\mathrm{~S} 3 \mathrm{cs}$ & $\begin{array}{l}\text { - Kelembaban udara relatif } \\
\text { - Kedalaman tanah } \\
\text { - Fragmen kasar } \\
\end{array}$ & $\begin{array}{l}\bullet- \\
\bullet- \\
\bullet- \\
\end{array}$ & $\begin{array}{l}\bullet- \\
\bullet- \\
\bullet- \\
\end{array}$ \\
\hline 2 & $\mathrm{~N} 1 \mathrm{cs}$ & $\begin{array}{l}\text { - Kelembaban udara relatif } \\
\text { - Kedalaman tanah }\end{array}$ & $\begin{array}{l}\bullet- \\
\bullet-\end{array}$ & $\begin{array}{l}\bullet- \\
\bullet-\end{array}$ \\
\hline 3 & N1csf & $\begin{array}{l}\text { - Kelembaban udara relatif } \\
\text { - Kedalaman tanah } \\
\text { - } \mathrm{CO}\end{array}$ & $\begin{array}{l}\text { - }- \\
\bullet- \\
\text { - Sedang (+) } \\
\end{array}$ & $\begin{array}{l}\text { - - } \\
\text { - - } \\
\text { - Bahan organik } \\
\end{array}$ \\
\hline 4 & N1csf & $\begin{array}{l}\text { - Kelembaban udara relatif } \\
\text { - Kedalaman tanah } \\
\text { - Fragmen kasar } \\
\text { - CO } \\
\end{array}$ & $\begin{array}{l}- \\
\bullet- \\
\bullet- \\
- \text { Sedang (+) } \\
\end{array}$ & $\begin{array}{l}\bullet- \\
\bullet- \\
\bullet- \\
\bullet \text { Bahan organik } \\
\end{array}$ \\
\hline 5 & $\mathrm{~N} 1 \mathrm{cs}$ & $\begin{array}{l}\text { - Kelembaban udara relatif } \\
\text { - Kedalaman tanah } \\
\text { - Fragmen kasar }\end{array}$ & $\begin{array}{l}\bullet- \\
\bullet- \\
\bullet- \\
\end{array}$ & $\begin{array}{l}- \\
\bullet- \\
\bullet-\end{array}$ \\
\hline 6 & S3cs & $\begin{array}{l}\text { - Kelembaban udara relatif } \\
\text { - Kedalaman tanah } \\
\text { - Fragmen kasar }\end{array}$ & $\begin{array}{l} \\
\bullet- \\
\bullet-\end{array}$ & $\begin{array}{l}- \\
\bullet- \\
\bullet-\end{array}$ \\
\hline
\end{tabular}

Faktor pembatas pertama adalah Masalah pada pertumbuhan tanaman yaitu fragmen kasar yang terdapat dalam solum tanah tidak cukup menyediakan ruang tanah yang pada dasarnya sulit diatasi, akar tanaman untuk memperoleh nutrisi sehingga dianggap sebagai faktor karena tertutup oleh fragmen sehingga pembatas yang tidak mudah diperbaiki. tanaman tidak berkembang. Perbaikan 
yang ada, tidak cukup berarti mengingat upaya yang dilakukan justru dapat merusak tanah itu sendiri, di samping itu pula memerlukan biaya yang cukup besar juga teknologi maju.

Faktor pembatas kedua adalah kedalaman tanah. Faktor pembatas kedalaman tanah pada dasarnya sulit diatasi, sehingga dianggap sebagai faktor pembatas yang tetap yang tidak dapat ditingkatkan kelas kesesuaian lahannya.

Faktor pembatas ketiga adalah Corganik ini dapat diatasi dengan pemberian bahan organik berupa pupuk organik. Pupuk organik tersebut dapat berupa pupuk kompos dan pupuk $\mathrm{kg}$ MoP, dan $8 \mathrm{~kg}$ kieserit. kandang. Pupuk kompos berasal dari hasil pengolahan sisa-sisa tanaman yang mengandung banyak mikroorganisme. Terkait pentingya bahan organik bagi ketersediaan hara, Berdasarkan penelitian Hanafiah (Hanafiah, 2007: 181) bahwa pupuk kandang dari kotoran ayam 20 ton/ha dapat meningkatkan nilai Corganik $0,43 \%$. Usaha meningkatkan kadar zat organik dapat pula dilakukan dengan memanfaatkan serasah sisa pemangkasan maupun pembenaman buah cokelat. Kulit buah cokelat sebagai mengandung zat organik sebanyak 900 $\mathrm{kg} / \mathrm{ha}$, dan dapat memberikan hara yang setara dengan $29 \mathrm{~kg}$ urea, $9 \mathrm{~kg} \mathrm{RP}, 56,6$

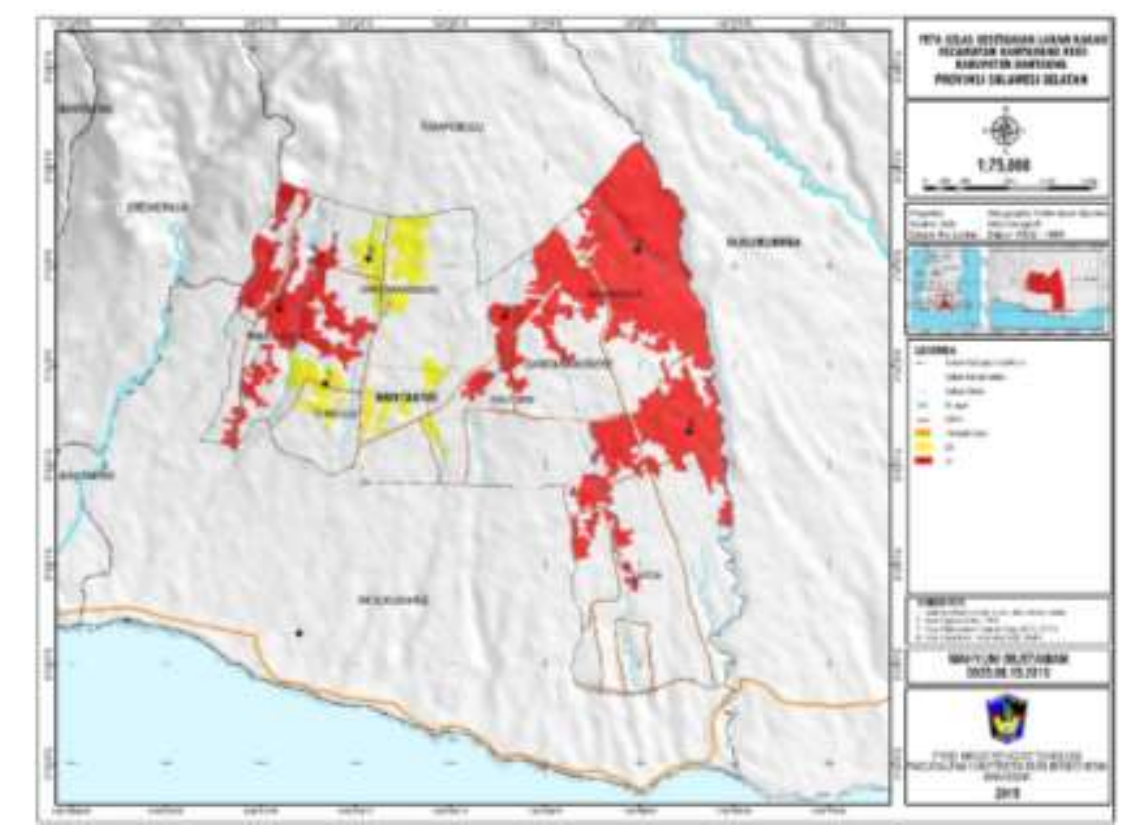

Gambar 2. Peta kesesuaian lahan kakao di lokasi penelitian 


\section{Analisis Ekonomi Kakao}

Produktivitas tanaman dari tahun ketahun cenderung mengalami peningkatan apabila digunakan jenis bibit sambung samping dan klon S1 dan S2, MCC 01, MCC 02, MCC 04, THR, GTB dan jenis klon lainnnya serta cara pemeliharaan yang tepat dan dilakukan peremajaan awal pada tanaman kakao. Penelitian Sari et al. (2012) menyimpulkan bahwa terdapat tiga kelompok batang atas kakao berdasarkan karakter pertumbuhan dan daya hidup yaitu kelompok yang memiliki kemampuan hidup tinggi dan pertumbuhan baik (KW 570), kelompok yang memiliki daya hidup dan pertumbuhan sedang (ICCRI 05, ICCRI 05, sulawesi 1 (S1), sulawesi 2 (S2), KW 514, KW 165) serta kelompok yang memiliki daya hidup tinggi dan pertumbuhan kurang (ICCRI 01, dr 2, KW 516, KW 617, KW 604).

Tanaman yang dipelihara dengan baik mampu berproduksi sampai umur 20 tahun atau lebih apabila dilakukan peremajaan lebih awal. Upaya rehabilitasi tanaman kakao untuk memperbaiki atau meningkatkan potensi produktivitas dan salah satunya dilakukan dengan teknologi sambung samping (side grafting).
Menurut Prastowo et al., (2006) sambung samping merupakan teknik perbaikan tanaman yang dilakukan dengan cara menyisipkan batang atas (entris) dengan klon-klon yang dikehendaki sifat unggulnya pada sisi batang bawah. Tujuan sambung samping adalah memperbaiki tanaman yang rusak secara fisik, menambah jumlah klon dalam populasi tanaman sehingga produktivitas dan mutu biji dapat ditingkatkan dapat juga digunakan untuk, dan pemendekan tajuk tanaman.

Berdasarkan hasil wawancara langsung dengan petani pada daerah penelitian. Kelayakan pada daerah penelitian berdasarkan dari jumlah tanggungan keluarga dan pendapatan per tahun yang dicapai petani yang dikaitkan dengan kebutuhan konsumsi beras dalam desa per tahun sebesar $320 \mathrm{~kg} / \mathrm{th}$ menurut Sajogyo (1977).

Berdasarkan data pendapatan petani pada kelas kesesuaian lahan S3 sebesar Rp. 13.901.650/th sedangkan pada N1 sebesar Rp. 7.656.600/th. Jika dikaitkan dengan kebutuhan konsumsi beras per kepala keluarga dan harga beras yang berlaku di lokasi penelitian yaitu Rp.10.000/kg dan dikalikan dengan kebutuhan konsumsi beras dalam desa 
sebesar $320 \mathrm{~kg} / \mathrm{th}$ maka daerah penelitian untuk kelas kesesuaian lahan S3 dapat dikatakan memiliki kehidupan yang layak apabila memiliki jumlah tanggungan keluarga adalah 4 orang dengan jumlah pengeluaran Rp.12.800.000/th dan tidak layak jika memiliki jumlah tanggungan di atas 4 orang dengan jumlah pengeluaran Rp. 16.000.000 yang melebihi dari jumlah pendapatan sedangkan kelas kesesuaian lahan N1 dapat dikatakan memiliki kehidupan yang layak apabila memiliki jumlah tanggungan keluarga adalah 2 orang dengan jumlah pengeluaran Rp.6.400.000/th dan tidak layak jika memiliki jumlah tanggungan di atas 2 orang dengan jumlah pengeluaran $\mathrm{Rp}$. 9.600.000 yang melebihi dari jumlah pendapatan. Menurut Sajogyo (1977) menggunakan tingkat konsumsi ekuivalen beras per kapita sebagai indikator kemiskinan dengan membedakan tingkat ekuivalen konsumsi beras di daerah pedesaan dan perkotaan. Untuk daerah pedesaan, apabila seseorang hanya mengkonsumsi ekuivalen beras kurang dari $320 \mathrm{~kg} / \mathrm{orang} / \mathrm{th}$, maka yang bersangkutan digolongkan miskin dan sangat miskin apabila dibawah 240kg/org/th, sedangkan untuk daerah perkotaan ditentukan sebesar ekuivalen $480 \mathrm{~kg}$ beras/ orang/ tahun.

Jika dikaitkan dengan pendapatan per kapita Kabupaten Bantaeng tahun 2017 Rp.856.592 (BPS Kabupaten Bantaeng, 2018), daerah penelitian pada kelas kesesuaian lahan S3 dengan 4 orang tanggungan keluarga dengan rata-rata pengeluaran per kapita sebesar Rp. 3.426.368 sedangkan pada kelas kesesuaian lahan N1 dengan 2 orang tanggungan keluarga dengan rata-rata pengeluaran per kapita sebesar Rp. 1.713.184, maka pendapatan di lokasi penelitian lebih besar bila dibandingkan dengan pendapatan per kapita dan menunjukkan nilai $\mathrm{R} / \mathrm{C}$ antara $2-34$ yang berarti layak untuk diusahakan karena memberikan keuntungan di Kecamatan Gantarangkeke karena nilai $\mathrm{R} / \mathrm{C}$ ratio $>1$. Hal ini sesuai dengan pendapat Soekartawi (1995), jika R/C ratio > 1, berarti layak untuk diusahakan sebaliknya $\mathrm{R} / \mathrm{C}$ ratio di $<1$, berarti tidak layak untuk diusahakan dan $\mathrm{R} / \mathrm{C}$ ratio sama dengan 1 , berarti usaha tidak untung dan tidak rugi. 


\section{KESIMPULAN}

\section{Kesimpulan}

Berdasarkan hasil evalusi kesesuaian lahan untuk pengembangan tanaman kakao di Kecamatan Gantarangkeke, Kabupaten Bantaeng, maka dapat disimpulkan bahwa:

1. Kelas kesesuaian lahan tanaman kakao tergolong kelas S3 (sesuai marginal) dengan luas 289 ha meliputi titik pengamatan 1 dan titik pengamatan 6 sedangkan N1 (tidak sesuai saat ini) dengan luas 1634 ha meliputi titik pengamatan 2, 3, 4, dan 5 .

2. Faktor yang menjadi pembatas lahan pada kelas kesesuaian lahan S3cs yaitu iklim (kelembaban udara relatif), sifat fisik tanah (kedalaman tanah dan fragmen kasar), kelas kesesuaian lahan N1csf yaitu iklim (kelembaban udara relatif), sifat fisik tanah (kedalaman tanah dan fragmen kasar), dan kesuburan tanah (c-organik), dan kelas kesesuaian lahan N1cs yaitu yaitu iklim (kelembaban udara relatif), sifat fisik tanah (kedalaman tanah dan fragmen kasar).

3. Pendapatan petani eksisting untuk tanaman kakao yang tergolong kelas S3 (sesuai marginal) Rp. 13.901.650/th dan N1 (tidak sesuai saat ini)
Rp.7.656.600/th. Bila dikaitkan dengan kemiskinan menurut Sajogyo (1977), yang tergolong kelas S3 (sesuai marginal) dengan jumlah pengeluaran 12.800.000/th dengan 4 orang tanggungan dan N1 (tidak sesuai saat ini) dengan jumlah pengeluaran 6.400.000/th dengan 2 orang tanggungan, maka daerah penelitian layak karena berada di atas garis kemiskinan. Jika dibandingkan dengan pendapatan per kapita Kabupaten Bantaeng tahun 2017 sebesar Rp. 856.592, yang tergolong kelas S3 (sesuai marginal) dengan jumlah tanggungan 4 orang sebesar Rp. 3.426.368 dan N1 (tidak sesuai saat ini) dengan jumlah tanggungan 2 orang sebesar Rp. 1.713.184, maka pendapatan petani di lokasi penelitian lebih besar bila dibandingkan dengan pendapatan per kapita dan nilai $\mathrm{R} / \mathrm{C}$ daerah penelitian berkisar anatar $2-34$ yang berarti layak untuk dikembangkan tanaman kakao.

\section{Saran}

Berdasarkan kesimpulan di atas maka penelitian ini memberikan informasi dan saran untuk peningkatan kualitas lahan khususnya untuk pembudidayaan 
tanaman kakao, diantaranya sebagai berikut:

1. Melakukan penanganan terhadap karakteristik lahan yang menjadi faktor penghambat bagi pertumbuhan tanaman kakao dengan tindakan perbaikan pada pada sifat fisik tanah dengan penambahan bahan organik ke tanah.

2. Memanfaatkan lahan untuk budidaya tanaman kakao dengan tetap memperhatikan pengelolaan lahan yang sesuai dengan kesesuaian lahan serta manajemen budidaya yang baik.

\section{DAFTAR PUSTAKA}

[BPS] Badan Pusat Statistik. 2016. Statistik Kakao Indonesia 2016. Jakarta: Badan Pusat Statistik.

[BPS] Badan Pusat Statistik. 2017. Statistik Daerah Provinsi Sulawesi Selatan 2017. Makassar: Badan Pusat Statistik Provinsi Sulawesi Selatan.

[BPS] Badan Pusat Statistik. 2018. Kecamatan Gantarangkeke Dalam Angka 2018. Bantaeng: Badan Pusat Statistik Kabuaten Bantaeng.

[BPS] Badan Pusat Statistik. 2018. Kabupaten Bantaeng Dalam Angka 2018. Bantaeng: Badan Pusat Statistik Kabuaten Bantaeng.

Baja, S. 2012a ${ }^{\mathrm{a}}$. Metode Analitik Evaluasi Sumber Daya Lahan: Aplikasi GIS, Fuzzy Set, dan MCDM. Penerbit Identitas Universitas Hasanuddin. Makassar.
Baja, S. 2012 ${ }^{\mathrm{b}}$. Perencanaan Tata Guna Lahan dalam Pengembangan Wilayah - Pendekatan Spasial dan Aplikasinya. Yogyakarta: Penerbit Andi.

Lopulisa, C., dan Hernusye, H. 2011. Evaluasi Lahan 1. Prinsip Dasar dan Kalkulasi Produksi Tanaman. Penerbit LP2M Universitas Hasanuddin. Makassar.

Prastowo, N.H., J.M. Roshetko, G.E.S. Maurung, E. Nugraha, J.M. Tukan dan F. Harun. 2006. Teknik Pembibitan dan Perbanyakan Vegetatif Tanaman Buah. World Agroforestry Centre (ICRAF) \& Winrock International. 92 hal.

Pusdatin Pertanian. 2016. Outlook Kakao. Pusat Data dan Sistem Informasi Pertanian Kementerian Pertanian. Jakarta.

Sajogyo. 1977. Garis Kemiskinan dan Kebutuhan Minimum Pangan. Pusat Studi Pembangunan Pertanian dan Perdesaan. LPPM - Institut Pertanian Bogor. Bogor.

Sari, I.A dan A.W. Susilo. 2012. Keberhasilan Sambungan pada Beberapa Jenis Batang Atas danFamili Batang Bawah.Kakao (Theobroma cocoa L. Pelita Perkebunan, Coffee and Cocoa Research Journal (CCRJ) 28(2) 2012,72-81. Pusat Penelitian Kopi dan Kakao Indonesia. Jember

Soekartawi. 1995. Analisis Usahatani. Universitas Indonesia press. Jakarta

Sys, C., E. V. Ranst, dan J. Debaveye. 1991. Land Evaluation part II Methods in Land Evaluation. General Administration for Development Cooperation Place du Champ de Mars 5 bte 57 - 1050 Brussels - Belgium.

Sys, C., E. V. Ranst, J. Debaveye, and F. Beernaert. 1993. Land Evaluation 
Wahyuni Mustaman: Evaluasi Kesesuaian Lahan dan Kelayakan Ekonomi Tanaman Kakao Di Kecamatan Gantarang Keke Kabupaten Bantaeng

part III Crop Requirements. General Administration for Development Cooperation Place du Champ de Mars 5 bte 57 - 1050 Brussels Belgium.
Kabupaten Kolaka dan Kolaka Timur, Sulawesi Tenggara [disertasi]. Institut Pertanian Bogor. Bogor.

Yanto, E. 2016. Kriteria Kesesuaian

Lahan untuk Tanaman Kakao di

Appendix 1. Persyaratan iklim untuk tanaman kakao

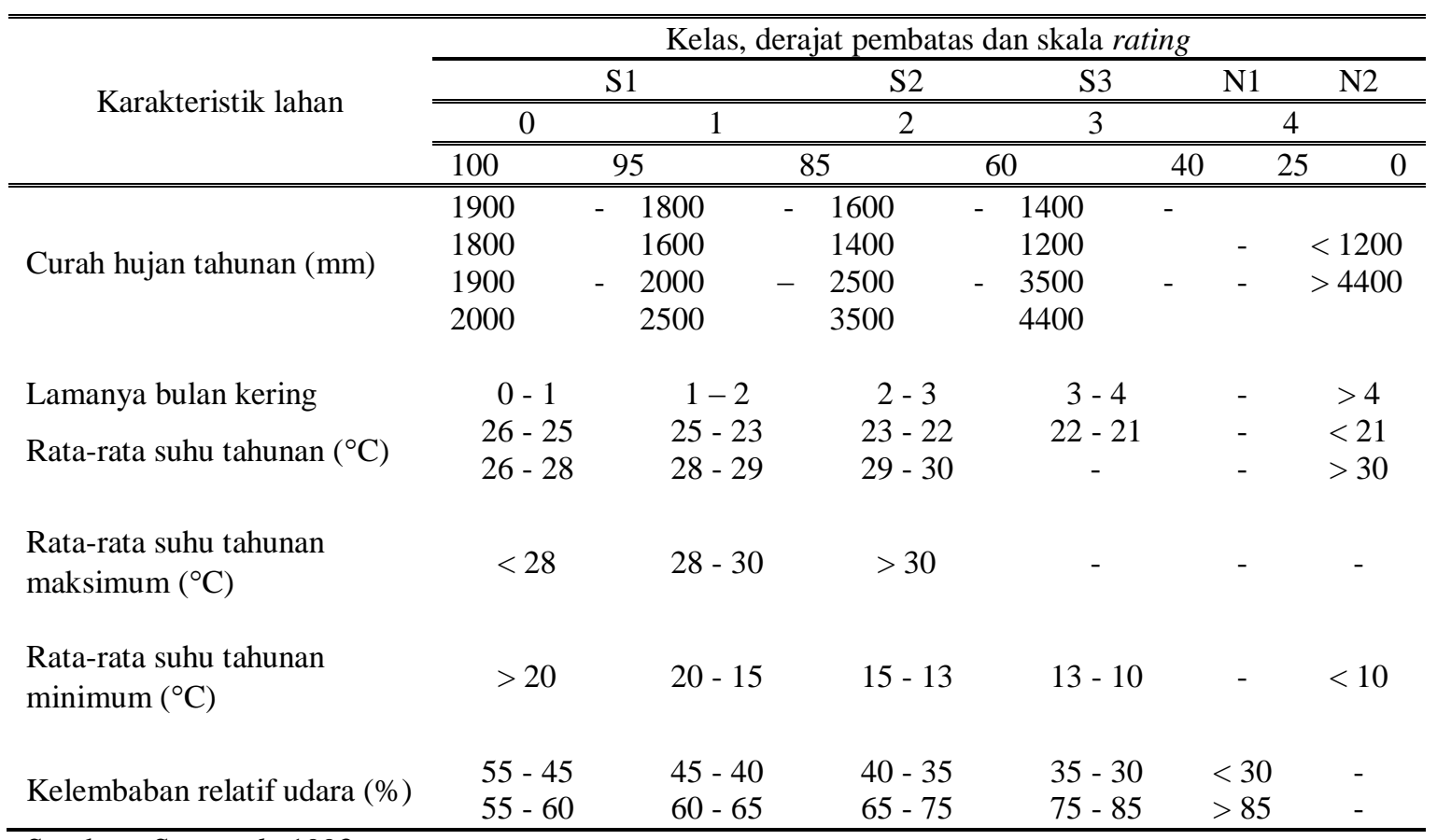

Sumber : Sys et al., 1993 
Wahyuni Mustaman: Evaluasi Kesesuaian Lahan dan Kelayakan Ekonomi Tanaman Kakao Di Kecamatan Gantarang Keke Kabupaten Bantaeng

Appendix 2. Persyaratan lahan untuk tanaman kakao

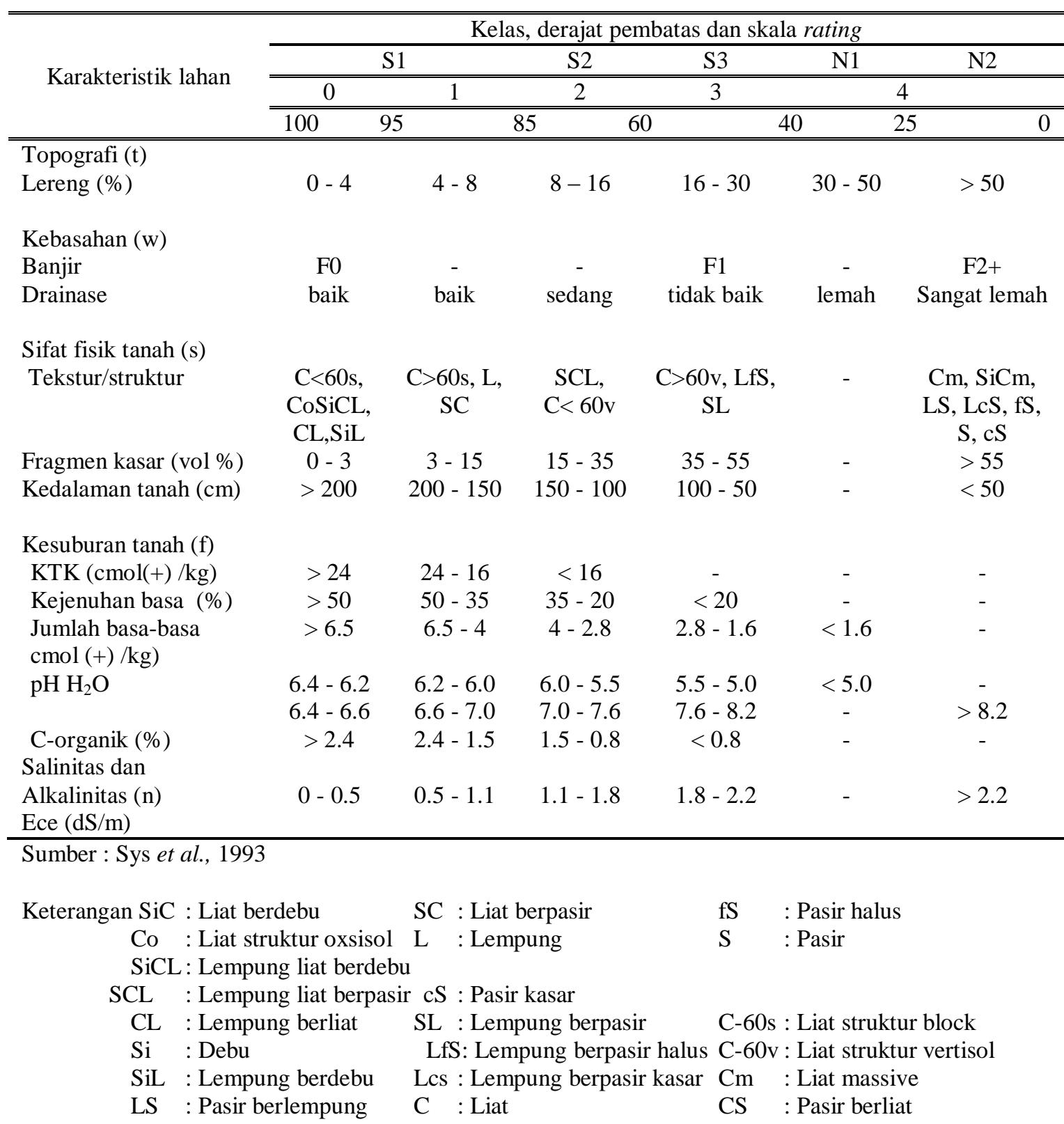

